\title{
FILSAFAT SENI NUSANTARA
}

\section{Oleh: Sunarto}

Jurusan Sendratasik, Fakultas Bahasa dan Seni, Universitas Negeri Semarang sunartounnes@gmail.com

\begin{abstract}
Abstrak
Elemen-elemen dalam filsafat, meliputi: Ada (Being) (Metafisika dan Ontologi); Pengetahuan (Knowledge) (Epistemologi, Metodologi, Logika, dan Filsafat Ilmu); Nilai/Aksiologi (Value) (Etika dan Estetika). Filsafar seni Nusantara mempunyai 3 elemen: Being, Knowledge, Value. Seni Nusantara tersebar mulai dari Sabang sampai Papua, yang jumlahnya mencapai ribuan. Filsafat seni Nusantara merupakan rangkuman dari dari eksistensi seni dari Sabang sampai Papua. Konteks seni Nusantara, walaupun ada beratus jenis seni namun, seperti konsep ontologisnya Plotinus, tetap berpegang pada yang Transenden. Alam raya (empiris) Nusantara telah memberikan dasar ontologis penciptaan bagi seniman Nusantara (Aristoteles). Secara epistemologis, seni Nusantara mempunyai: sumber pengetahuan, batas pengetahuan, struktur pengetahuan, dan keabsahan pengetahuan. Dalam konteks aksiologi, seni Nusantara terdiri dari 4 jenis nilai, yaitu: kekudusan (holiness), kebaikan (goodness), kebenaran (truth), dan keindahan (beauty). Ketiga elemen dalam filsafat membentuk rajutan dalam seni Nusantara. Elemen-elemen tersebut saling menjalin kesinambungan dan harmoni.
\end{abstract}

Kata kuci: Seni Nusantara, filsafat, being, knowledge, value, holiness, goodness, truth, beauty. 


\title{
THE PHILOSOPHY OF ARTS OF INDONESIAN ARCHIPELAGO
}

\begin{abstract}
The elements in philosophy include Being (in Metaphysics dan Ontology); Knowledge (in Epistemology, Metodology, Logic, and Science Philosophy); and Value (Ethics and aesthetics). Thousands of arts of Indonesian archipelago are spread from Sabang to Papua whose philosophy is the combination of the existence of arts all over Indonesia. The context of Indonesian arts is in line with Plotinus' concept of ontology, which holds transcedence values. Indonesia's nature has laid the base for the ontology of creativity for Indonesian artists (Aristoteles). In the view of epistemology, Indonesian arts have sources of knowledge, limitation of knowledge, structures of knowledge, and the legalization of knowledge. In the context of axiology, Indonesian arts have four kinds of value: holiness, goodness, truth, and beauty. Those elements interweave each other continuously forming harmony in Indonesian arts.
\end{abstract}

Keywords: Indonesian arts, philosophy, being, knowledge, value, holiness, goodness, truth, beauty.

\section{PENDAHULUAN}

Manusia hidup tidak lepas dari budayanya, karena budaya itu sendiri merupakan ekspresi eksistensi manusia (The Liang Gie,1979). Ekspresi manusia dalam kebudayaannya mempunyai keberagaman. Keragaman ekspresi ini menjadi ciri bahwa manusia makhluk berkesadaran (Dalam diri kesadaran ada ada unsur: kebenaran, keindahan, dan kebaikan). Seni salah satu wujud ekspresi eksistensi manusia.Suzanne K. Langer (1955) mengatakan, bahwa ekspresi seni berbeda dengan ungkapan emosional maupun perasaan (fenomenal). Ekspresi seni bukanlah ekspresi diri, karena ekspresi seni merupakan sebuah nilai keindahan dan dapat memperhalus sifat komunikasi menjadi suatu harmoni rasa. Di sni diartikan ekspresi seni menjadi perantara pengalaman subjektif seniman dengan orang lain. Seni dapat menjadi alat pendidikan seperti konsepsi dari Plato (427-347 SM). Tetapi nilai seni tidak langsung, karena bersifat simbol.

Immanuel Kant (1724-1804) memberikan dasar-dasar pemahaman dunia seni melalui: perasaan, pengetahuan, dan kehendak. Menurut Kant, pertimbangan atas keindahan adalah identik dengan pertimbangan selera, tidak menunjukkan sesuatu di 
dalam objek karya seni, dan karenanya lebih bersifat subjektif (Kant, 1952). Seorang sejarawan seni, E.H. Gombrich mengatakan bahwa, sangat sulit mendefinisikan apa yang disebut "seni"; ada perbedaan-perbedaan interpretasi dari para filsuf.

Membicarakan tentang seni tidak bisa lepas dengan estetika (Dick Hartoko, 2000). Estetika diartikan sebagai filsafat keindahan. Ada dua macam estetika: estetika alam dan estetika seni. Estetika alam memperbincangkan keindahan alam raya sebagai bentuk ciptaan Yang Illahi; sedangkan estetika seni memperbincangkan keindahan seni sebagai karya manusia. Sampai saat ini seni dan keindahan masih menjadi perbicangan yang hangat (Coper, 2002:155.). Seni dan dan keindahan muncul menggugat manusia dan sekaligus muncul untuk digugat oleh manusia itu sendiri. Hal ini mirip seperti yang diungkap Thomas Merton: art enables us to find ourselves and lose ourselves at the same time.

Apakah seni juga menyangkut suatu kewilayahan geografi atau budaya? Pertanyaan ini selalu menyertai setiap kali bertatapan dengan sejarah seni (history of art/arts). Ada fakta-fakta historis bahwa seni berasal dari suatu wilayah tertentu, akan tetapi juga ada yang berasal dari kebudayaan tertentu. Wilayah georgrafi dengan wilayah kebudayaan dua hal yang berbeda. Yang pertama, menyangkut kewilayahan bumi secara (fisik, daerah tertentu); yang kedua menyangkut wilayah kebudayaan, yang berarti suatu ide. Hal ini menjadi suatu ambigu, bahwa seni seakan tak bertuan dari mana asal usulnya. Memang, seni tidak bisa disikapi dengan membelah dunia seni manjadi dua kutub yang berbeda, seperti: "seni Timur dan Barat", tetapi dipandang perlu juga dalam hal tertentu mengambil ide 'pembelahan' dalam rangka pemahaman spesifik.Hal ini terjadi seperti pada Seni Nusantara. Ada pertanyaan yang selalu diajukan: "Bagaimana/ apa/dari mana Seni Nusantara?"

Istilah Nusantara untuk pertamakalinya disebutkan dalam konsep Cakrawala Mandala Dwipantarayang dicetuskan pada tahun 1275 oleh Kertanegara, Raja Singhasari. Dwipantara (Sanskerta) untuk menyebut"kepulauan antara", yang artinya sama dengan Nusantara, kata"dwipa" sinonim dengan"nusa" yang bermakna "pulau". Kertanegara memiliki ambisi untuk menyatukan beberapa kerajaan di wilayah Asia Tenggara dalam rangka mengatisipasi ancaman dari Kerajaan Mongol yang agresif. Kemudian tahun 1336 diucapkan lagi oleh Gajah Mada, dengan Sumpah Palapa-nya. 
Sira, Gajah Mada pepatih amungkubumi tan ayun amukita palapa, sira Gajah Mada: Lamun huwus kalah Nusantara ingsun amukti palapa, lamun kalah ring Gurun, ring Seram, Tanjungpur, ring pahan, Dompo, ring Bali, Sunda, Palembang, Tumasik, samana ingsun amukti palapa.

Aku, Gajah Mada Patih Amangkubumi tidak ingin melepaskan puasa. Aku, Gajah Mada: "Jika telah mengalahkan pulau-pulau lain, saya (baru akan) melepaskan puasa. Jika mengalahkan Gurun, Seram, Tanjung Pura, Haru, Pahang, Dompo, Bali, Sunda, Palembang, Tumasik, demikianlah saya (baru akan) melepaskan puasa."

Secara morfologi, kata "Nusantara" merupakan kata majemuk yang diambil daribahasa Jawa Kuna,Nusa(pulau) dan Antara(lain/seberang). Dalam Kitab Negarakertagamadituliskan wilayah "Nusantara", dalam wilayah teritorial saat ini mencakup sebagian besar wilayah modern Indonesia (Jawa, Sumatra, Kalimantan, Nusa Tenggara, sebagian Sulawesi dan pulau-pulau di sekitarnya, sebagian Kepulauan Maluku, dan Papua Barat) ditambah wilayah Malaysia,Singapura, Brunei, dan sebagian kecil Filipina bagian selatan.

Ki Hajar Dewantara pada tahun 1920-an kembali merevitalisasi nama "Nusantara" untuk menyebut wilayah Hindia Belanda.Hal ini memang lebih cenderung nuansa politisnya.KataNusantara dipakai sebagai salah satu alternatif karena tidak memiliki unsur bahasa asing (India atau Belanda).

Seni Nusantara suatu istilah yang memang perlu dibicarakan lebih lanjut. Karena ini menyangkut eksistensi manusia (seniman) Nusantara dalam berekspresi. Seni Nusantara telah menjadi perbincangan di berbagai forum. Seni Nusantara merupakan eksistensi seni yang ada di dalam wilayah Nusantara, yang meliputi dari Sabang sampai Papua. Suatu wilayah geografi yang sangat luas dan dengan pluralitas budayanya. Memang sulit mendapat jawaban yang tepat pertanyaan tentang: "Bagaimana/apa/dari mana Seni Nusantara?"

Kemudian dalam tataran ideologi terjadi pertanyaan yang sama, yaitu: "Adakah Filsafat Seni Nusantara?" "Bagaimana filsafat Seni Nusantara?” Pertanyaan-pertanyaan tersebut memang memerlukan jawaban. Jawabannya pun akan selalu berkembang, tidak ada kata the end. Tidak ada satu buku atau artikel pun (sepengetahuan penulis) yang mengulas tentang Filsafat Seni Nusantara. Filsafat Seni Nusantara mengadaikan universalitas formal filsafat Barat. Karena istilah-istilah yang dipakai merupakan produk Barat yang telah menjadi konvensional. 


\section{FILSAFAT}

Dalam filsafat tidak hanya mencari kebenaran, tapi bertanya: "Apa itu kebenaran?"

Kata Yunani,,philosophia (dari philein, mencuntai, atau philia, cinta; dan sophos, kearifan), yang melahirkan kata Inggris philosophy, yang biasanya diterjemahkan sebagai "cinta kearifan/kebijaksanaan". Dalam traktat tradisional dari Yunani Kuno, Pythagoras (572-497 SM), dinyatakan sebagai orang yang pertama-tama memakai kata philosophia. Ketika ditanya apakah ia orang yang arif, Pythagoras hanya menjawab bahwa ia seorang philosophos, artinya: "pencinta kearifan" (Cottingham , 1996:12).

Berbagai sumber menegaskan bahwa sophia mempunyai arti yang lebih luas daripada kearifan saja, seperti: kerajinan, kebenaran, pengetahuan, kebajikan, intelektual, akal sehat (commonsense). Jadi, pada dasarnya, filsafat asal mulanya merupakan kata yang sangat umum untuk menyebut usaha mencari kebenaran(Sontag, 1984:7).

Bertrand Russell (1872-1970) mendefinisikan filsafat sebagai 'wilayah tak bertuan', yaitu antara teologi dan ilmu pengetahuan (Russell, 1950:1). Seperti halnya teologi, filsafat bermuatan spekulasi terhadap semesta dimana hal tersebut tidak diakui dalam ilmu pengetahuan. Namun, di sisi lain, filsafat juga memiliki sifat ilmu pengetahuan yang lebih mengutamakan rasionalitas dari otoritas. Definisi dari Russell tersebut mengadaikan bahwa filsafat merupakan disiplin tersendiri yang mempunyai keluasan dalam jangkauan rasionalitas, yang tidak terjebak dalam teologi dan ilmu pengetahuan.

Melalui pendekatan definisi akan dapat dilihat bagaimana perbedaan antara filsafat dengan teologi ataupun ilmu pengetahuan. Teologi mengkaji semesta supraindrawi (yang Transenden), sedangkan ilmu pengetahuan hanya mengkaji sebatas fenomena yang tampak dan berusaha menjelaskan secara kausalistik.

Pada kenyataannya, jarang sekali seorang filsuf membahas tiga wilayah sistematika secara tuntas. Seorang filsuf biasanya terfokus pada satu atau dua wilayah sistematika saja. Hanya seorang filsuf yang cukup brilian, seperti Immanuel Kant (1724-1804) yang mampu menjelajahi ketiga wilayah sistematika filsafat secara lengkap, dengan dituangkannya ke dalam tiga bukunya, yaitu: Critic of Practical 
Reason (1788) (Apa yang dapat diharapkan?); Critique of Judgement (1790) (Apa yang dapat dilakukan?); dan Critique of Pure Reason (1781) (Apa yang dapat diketahui?).

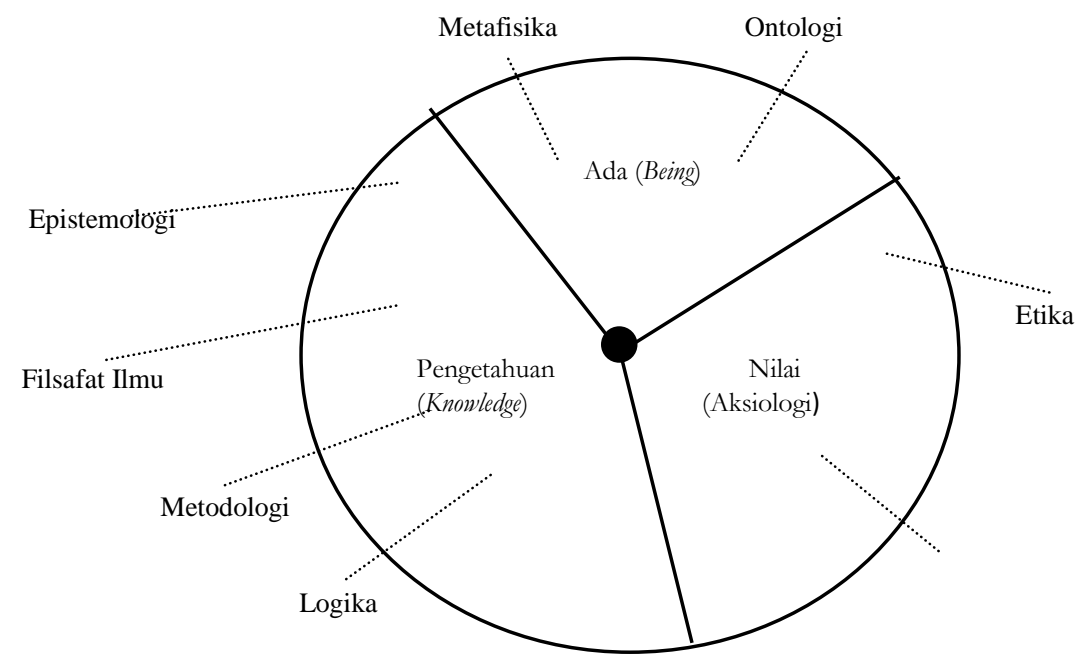

Wilayah Ada (Being): Ontologi dan Metafisika. Ontologi sebagai cabang filsafat yang mengkaji dengan 'yang ada sebagai yang ada' atau 'yang sebenar-benarnya ada', sebagai lawan dari disiplin yang mengkaji bentuk partikular ada, seperti: biologi, antroplogi, fisika, psikologi, atau sosiologi. Metafisika sebagai cabang filsafat yang mengkaji semesta di balik empiris. Seorang filsuf, Christian Wolff, mengemukakan bahwa ontologi mempunyai wilayah tentang semesta empiris sedangkan metafisika dengan wilayah semesta di balik fenomena empiris (Bagus, 1991:19-20; Sontag, 1984:2-10).

Wilayah Nilai (Aksiologi): Estetika dan Etika. Estetika sebagai disiplin filsafat yang merfleksikan nilai-nilai estetis. Sedangkan etika cabang filsafat yang merefleksikan nilai-nilai moral.

Wilayah Pengetahuan (Knowledge). Pertama, Epistemologi adalah cabang filsafat yang mengkaji hakiki pengetahuan dari empat (4) segi, yaitu: sumber pengetahuan, batas pengetahuan, struktur pengetahuan, dan keabsahan pengetahuan. Kedua, Filsafat Ilmu Pengetahuan sebagai cabang filsafat yang mengkaji ilmu pengetahuan dari segi ciri-ciri dan cara-cara pemerolehannya. Ketiga, Logika sebagai cabang filsafat yang mengkaji azas-azas berpikir secara sistematis dan terbit. Keempat, Metodologi sebagai cabang filsafat yang mengkaji metode-metode yang digunakan dalam dunia ilmiah. 


\section{FILSAFAT SENI NUSANTARA}

Tidak mudah mengkonstruks filsafat seni Nusantara, yang mempunyai wilayah sangat luas dari Sabang sampai Papua; yang mempunyai ribuan seni, baik seni pertunjukan maupun seni rupa (Brandon, 2003; Holt, 2000; Denys, 2005). Namun, hal itu bukan berarti tidak dapat memberikan gambaran selintas tentang filsafat seni Nusantara. Seni Nusantara di sini dimaksud sebagai seni yang tumbuh sebelum kata "Indonesia" ditetapkan sebagai nama kebangsaan bagi negara independen dari Hindia Belanda pada Kongres Pemuda II (1928). Setelah kata "Indonesia" resmi dipakai, kata "Nusantara" tidak lagi bergema seperti sebelum tahun 1928. Kata "Nusantara" dipopulerkan kembali pada tahun 1960-an oleh kelompok band Koes Plus.

\section{Ontologi}

Ontologi (ontology, Inggris; dari akar kata Yunani, on, ontos, yang berarti: ada, keberadaan); dan logos (ilmu tentang, studi tentang). Dalam konteks dengan filsafat seni Nusantara, ontologi dimaksudkan dalam 3 pengertian, yaitu: a) meneliti status realitas seni Nusantara; b) meneliti jenis realitas dimiliki hal-hal dalam seni Nusantara; c) meneliti realitas yang menentukan apa yang disebut realitas atau ilusi dalam seni Nusantara.

Mimesis (istilah Yunani yang berarti imitasi atau tiruan). Istilah mimesis pertamakali diperkenalkan oleh Plato, yang berkata bahwa, waktu adalah bayangan yang bergerak dari kekekalan. Maksud dari Plato adalah bahwa dunia ini merupakan bayangan atau tiruan forma atau ide kekal. Kemudian dari Plato ini muncul ilmu seni memetik

Realitas yang ditampilkan dalam seni Nusantara bukan sepenuhnya dalam ranah mimesis Plato, yang bersifat idealis. Pendapat Plato ditentang oleh muaridnya sendiri, Aristoteles (384-322 SM), yang menyatakan bahwa seni tiruan (seni Nusantara) tidak niscaya suatu benda aktual, tetapi suatu hal yang mungkin.

Seni Nusantara berangkat dari realitas, bukan dari dunia idea seperti konsepsi Plato. Ia lahir dari realitas yang dideformasi oleh si seniman ke dalam bentuk karya. Landasan ontologis seni Nusantara memang lebih dekat dengan konsepsi Aristoteles. Menurut Aristoteles, seperti juga Plato, Seni Nusantara merupakan sebuah tiruan/imitasi 
dari dunia manusia dan dunia alamiah. Tetapi Aristoteles menekankan seni (Nusantara) tidak hanya tiruan dari benda yang ada di alam, tetapi lebih sebagai imitasi dari sesuatu yang universal; bentuk-bentuk tidak terpisah dari dunia empiris, karena dia tidak memiliki keberatan terhadap dunia empiris dan seni yang meniru dunia inderawi. Dalam konteks teori imitasi Aristoteles, dalam seni Nusantara memiliki 3 aspek imitasi, yaitu: a) media imitasi; b) objek imitasi; dan c) cara mempraktekkan imitasi.Media imitasi, berupa unsur-unsur dalam seni, seperti: warna, garis, nada, ritme, bahasa, gerak. Objek imitasi: aktivitas seniman. Cara mempraktekkan imitasi: gambar, cerita, gerak, nada, dibawakan atau dipraktekkan.

Dari landasan ontologis seni Nusantara a la Aristoteles tersebut kemudian memunculkan teori katarsis (bahasa Yunani, katharsis, yang berarti: bersih dari kesalahan atau pencemaran, pencucian). Seni Nusantara merupakan suatu proses pemurnian diri (katharsis). Di sini dimaksudkan bahwa lewat karya seni yang ditampilkan, seni Nusantara harus menjernihkan pikiran dan jiwa manusia. Hal ini bisa disimak dalam karya-karya seni yang agung yang ada di Nusantara. Hampir sebagaian besar lebih menggambarkan realitas yang mempunyai tujuan katharsis. Memang hal ini tidak bisa lepas dari peran ideologi senimannya (yang menurut istilah Aristoteles sebagai "penyebab efisien").

Yang Transenden. Disamping konsepsi dari Aristoteles tersebut, ada seorang Plotinus (206-270 M) yang dapat dijadikan formal bagi landasan ontologis seni Nusantara. Realitas seni Nusantara adalah "religius". Hal ini seperti yang dikatakan Plotinus, bahwa puncak perkembangan seni (Nusantara) itu adalah pengalaman religius, atau pengalaman mistik. Keindahan Seni Nusantara bukan terletak di: nada, gerak, atau warna, tetapi keindahan itu akan terbentuk jika terjadi harmonisasi berbagai bagian yang berbeda satu sama lainnya. Harmonisasi itu akan terjadi bila ada heterogenitas bukan sebaliknya homogenitas. Sebuah lukisan primitif di gua-gua Papua diangap layak dalam komposisi kerena ada harmonisasinya; dan menurut Plotinus, semakin karya seni itu mendekati yang Transenden, akan semakin indahlah karya itu.

Seperti sebagain besar seni Nusantara, Plotinus mengesampingkan terhadap yang sekuler. Dari hal ini ada demarkasi antara outerbeauty dan innerbeauty.Outerbeauty hanya material saja, sedangkan innerbeauty adalah jiwa di dalam diri dan realitas yang digembarkan dalam dunia empiris, yang tidak dapat mengiabaikana moral.Jadi 
terbentuknya seni Nusantara karena senimannya tidak semata-mata meniru apa yang mereka lihat, tetapi kembali kepada prinsip-prinsip yang membentuk estetik karya seni, yaitu moral dan yang Transenden

\section{Epistemologi}

Epeistemologi (episteme, pengetahuan, ilmu pengetahuan; dan logos, pengetahuan, studi) dapat dikatakan "pengetahuan tentang pengetahuan" atau "teori pengetahuan". Adakah epistetmologi seni Nusantara? Pertanyaan ini memang sering terdengar dan jarang ada jawaban yang memuaskan. Epistemologi di sini dimaksud seperti dalam keterangan di atas, yaitu: sumber pengetahuan, batas pengetahuan, struktur pengetahuan, dan keabsahan pengetahuan(Gallagher, 2001: 5-8.). ${ }^{1}$

Sumber pengetahuan dari seni Nusantara adalah alam raya Nusantara, baik outerbeauty dan innerbeauty. Secara empiris, alam raya Nusantara memberikan bahan dasar yang melimpah bagi inspirasi para senimannya untuk berkaya. Telah terbukti karya-karya para seniman Nusantara yang mampu memberikan karya seni yang spektakuler, yang bahkan diakui dunia, seperti Candi Borobudur. Relief Candi Borobudur merupakan gambaran realitas manusia yang hidup di alam maya pada ini. Dalam relief-relief tersebut realitas manusia sejak lahir hingga kematian digambarkan dengan penuh nuansa estetis. Ada proses imitasi dan pembentukan kesadaran, baik moral maupun kepada yang Transenden.

Batas pengetahuan seni Nusantara ada pada imajinasi seniman yang berkarya. Imajinasi merupakan cara memahami realitas secara kreatif. Imajinasi juga merupakan kedalaman pikir manusia. Karya-karya besar dalam seni Nusantara tidak bisa lepas dari imajinasi senimannya. Dengan imajinasinya $\mathrm{Mpu}$ Tantular mampu menyusun kakawin Jawa Kuna yaitu kakawin Sutasoma, yang berisi Bhinneka Tunggal Ika(Kata tunggal ,satu; ika, itu. Secara harfiah Bhinneka Tunggal Ika diterjemahkan "Beraneka Satu Itu", yang bermakna meskipun berbeda-beda tetapi pada hakikatnya bangsa Indonesia tetap adalah satu kesatuan). Frasa ini berasal dari bahasa Jawa Kuna dan seringkali diterjemahkan dengan kalimat "Berbeda-beda tetapi tetap satu". Imajinasi Mpu Tantular ini menjadi karya besara bagi Nusantara, yang pada waktu itumengajarkan toleransi antara umat Hindu Siwa dengan umat Buddha. Kemudian,

\footnotetext{
${ }^{1}$ Kenenth T. Gallagher, 2001, Epistemologi: Filsafat Pengetahuan, hal. 5-8.
} 
Kakawin ini istimewa karena semboyan ini digunakan untuk menggambarkan persatuan dan kesatuan Bangsa dan Negara Kesatuan Republik Indonesia yang terdiri atas beraneka ragam budaya, bahasa daerah, ras, suku bangsa, agama dan kepercayaan.

Struktur pengetahuan dalam seni Nusantara adalah keterkaitan antara seni dengan konteksnya. Konteks di sini, seperti: senimannya dan kebudayaannya. Seni Nusantara berkaitan erat seni dengan lingkungan dimana seni tersebut lahir. Ide-ide kebudayaan terstruktur dalam karya seni itu. Seni jarang yang absolut, tetapi lebih sering ke programa.

Keabsahan pengetahuan seni Nusantara lebih bersifat kolektif-kolegial. Artinya, kebanyakan seni Nusantara dimiliki oleh komunitas masyarakat pendukungnya. Pribadi seniman sering lebur menjadi satu-kesatuan dalam komunitas. Keabsahan estetisnya besifat komunal. Keindahan disepakati bersama sebagai bnetuk keabsahan seni Nusantara.

\section{Aksiologi}

Aksiologi (axiology, Inggris; dari kata Yunani, axios, layak, pantas; dan logos, pengetahuan, studi) merupakan studi dan analisis tentang nilai-nilai. Wahana (2008:5) mengatakan bahwa, manusia tidak dapat hidup tanpa nilai; nilai sebagai suatu sifat atau kualitas yang membuat sesuatu berharga, layak diingini atau dikehendaki.Ada 4 jenis nilai yang melingkupu manusia, yaitu: kekudusan (holiness), kebaikan (goodness), kebenaran (truth), dan keindahan (beauty)(Pepper, 1950:40.).

Seni Nusantara dapat bersifat abstrak dan semesta dalam arti mengejar sesuatu cita agung yang menyangkut seluruh umat manusia, tapi juga dapat bersifat konkrit dan satu-satu dalam arti ditujukan pada individu yang tertentu dalam rangka suatu tujuan yang spesifik. Tujuan yang spesifik ini menyangkut suatu bentuk tindakan manusia. Ada dua macam tindakan manusia,yaitu:Tindakan Universil (TU) dan Tindakan Individuil (TI)(Osborne, 1980:297).

Pengetahuan manusia dapat dibedakan menjadi pengetahuan yang bercorak abstrak dan intelektual serta pengetahuan yang bercorak konkrit dan inderawi. Dalam hal yang pertama berarti bahwa pengetahuan itu mempunyai lingkupan penerapan yang umum untuk pelbagai gejala dan berlandaskan pada akal manusia, sedang dalam hal kedua berarti bahwa pengetahuan itu menunjuk pada suatu hal khusus dan berdasarkan 
pada indera manusia. Untuk mudahnya dan sesuai dengan penyifatan pada tindakan manusia, kedua macam pengetahuan manusia itu dapat dinamakan sebagai Pengetahuan Universal (PU) dan Pengetahuan Individual (PI).

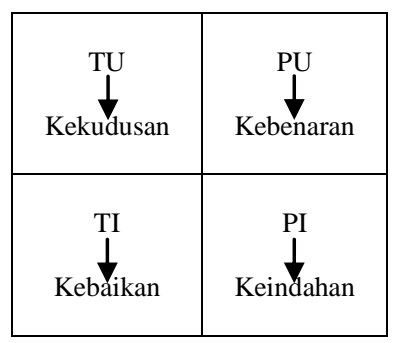

Dalam aksiologi seni Nusantara terjadi jalinan yang erat antara keempat jenis nilai, yaitu: a) Kekudusan adalah kebaikan yang sekaligus merupakan kebenaran; b) Kebaikan adalah kekudusan yang sekaligus merupakan keindahan; c) Kebenaran adalah keindahan yang sekaligus merupakan kekudusan; dan d) Keindahan adalah kebenaran yang sekaligus merupakan kebaikan.Keempat jenis nilai tersebut juga dapat dinyatakan dalam rumus, berikut ini: a) $\mathrm{TU} \quad=\mathrm{TI} \cup \mathrm{PU}$; b) $\mathrm{TI}=\mathrm{TU} \cup \mathrm{PI}$; c) $\mathrm{PU}=\mathrm{PI} \cup \mathrm{TU}$; dan d) PI= PU $\cup$ TI.

Selain saling mengandaikan seperti ternyata di atas, keempat jenis nilai itu juga saling berhubungan dan saling mempengaruhi satu sama lain, terutama pada perwujudannya dalam kehidupan manusia. Saling hubungan yang cukup kokoh dari sejumlah komponen akan membentuk suatu struktur dari komponen-komponen itu sebagai suatu kebulatan. Dengan demikian nilai-nilai manusiawi sebagai suatu kebulatan juga mempunyai sebuah struktur. Inilah struktur tersebut:

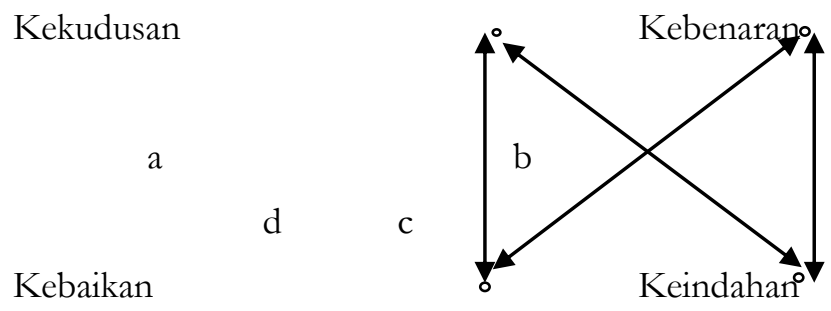

Dari struktur di atas ternyata nilai-nilai manusiawi itu mempunyai 4 macam interaksi, yaitu: a) Kekudusan dengan Kebaikan; b) Kebenaran dengan Keindahan; c) Kekudusan dengan Keindahan; dan d) Kebenaran dengan Kebaikan. Interaksi antara 
Kekudusan dengan Kebaikan dan antara Kebenaran dengan Keindahan merupakan hubungan sejenis. Kekudusan dan Kebaikan merupakan gejala yang sejenis, yaitu samasama berkaitan dengan tindakan. Demikian pula Kebenaran dan Keindahan adalah sejenis, yaitu keduanya berpautan dengan pengetahuan. Perincian selanjutnya dari hubungan sejenis ini boleh jadi berupa pengandungan semesta (superimplication) dan pengandungan sebagian (subimplication) seperti yang dikupas dalam logika tradisional.

Interaksi antara Kekudusan dengan Keindahan dan antara Kebenaran dengan Kebaikan merupakan hubungan dinamakan hubungan pelengkap. Dalam kerangka eksistensi manusiawi Kekudusan dan Keindahan saling memerlukan dan melengkapi, keduanya berkembang secara bersamaan dan seiring. Demikian pula halnya dengan Kebenaran dan Kebaikan. Hubungan komplemental ini dapat menjelaskan mengapa dalam perwujudannya Kekudusan dan Keindahan berinteraksi sehingga melahirkan misalnya seni Nusantara yang bersifat kudus atau seni religius (sacred art atau religious art).

Demikian pula hubungan pelengkap dari Kebenaran dan Kebaikan dapat membenarkan dan menjadilandasan filsafati dari ide yang sering diutarakan bahwa seorang seniman ataupun sarjana harus pula merupakan manusia susila.Struktur dari keempat jenis nilai manusiawi juga dapat dipergunakan untuk memperkuat ketepatan dari perumusan mengenai:Kekudusan, Kebaikan, Kebenaran, dan Keindahan (Osborne, 1980:102-110). Dengan mengamati struktur itu ternyata masing-masing nilai mencakup satu hubungan sejenis dan satu hubungan pelengkap dalam suatu pola yang identik. Hal ini dapat dilihat dari bagan, berikut ini: 


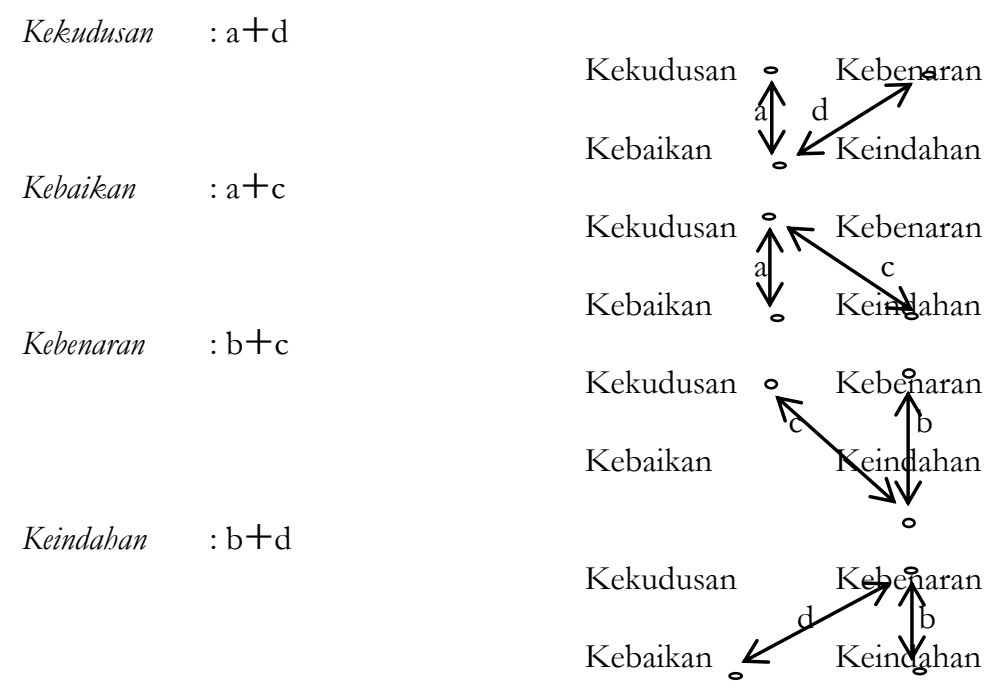

Di samping hal tersebut di atas, nilai seni Nusantara mempunyai segi subjektif maupun segi objektif. Aspek subyektif terjalin sangat erat dengan tindakan, pengalaman, dan sikap seniman. Aspek objektif berkaitan dengan benda dan situasi di luar manusia sendiri atau kebudayaan. Jadi sesuatu nilai tampil sejauh terdapat perilaku subjektif yang menanggapi sesuatu keadaan objektif yang tertentu dan bersamaan dengan itu ada keadaan objektif yang merangsang sesuatu perilaku subjektif yang tertentu. Dapat juga dikatakan sebaliknya bahwa suatu tindakan, pengalaman atau sikap tertentu dari seniman tergugah oleh keadaan objektif dan sekal.igus suatu benda atau situasi tertentu di luar manusia ditanggapi oleh perilaku subjektif (Frondizi, 2001:1923).

\section{PENUTUP}

Dalam memberikan rumusan filsafat seni Nusantara memang bukan pekerjaan yang gampang. Dilihat dari segi geografisnya saja, Nusantara membentang dari Sabang smapai Papua. Beribu pulau ada di Nusantara, beribu jenis seni terlahir dari beratus suku bangsa yang ada di Nusantara. Namun, Mpu Tantular telah mengikrarkan Bhinneka Tunggal Ika, dengan telunjuknya menunjuk kepada matahari di timur. Artinya, dalam konteks seni Nusantara, walaupun ada beratus jenis seni namun, seperti konsep ontologisnya Plotinus, tetap berpegang pada yang Transenden. Alam raya 
(empiris) Nusantara telah memberikan dasar ontologis penciptaan bagi seniman Nusantara (Aristoteles).

Rajutan epistemologis telah membentuk suatu teori pengetahuan tentang filsafat seni Nusantara, yang mempunyai:sumber pengetahuan, batas pengetahuan, struktur pengetahuan, dan keabsahan pengetahuan. Keempatnya memberikan dasar epeistemologis yang kuat dalam rangka membentuk estitika seni Nusantara.

Dalam aksiologi, terdapat 4 jenis nilai, yaitu: kekudusan (holiness), kebaikan (goodness), kebenaran (truth), dan keindahan (beauty). Keempatnya membentuk jalinan tidak terpisahkan dalam seni Nusantara. Sebagai contoh keindahan harus ada kebaikan. Karena dalam seni Nusantara tidak ada kata "seni untuk seni” (art for art), tetapi "seni untuk sesuatu". Keindahan sebuah lukisan haruslah menuju ke kebaikan, yang pada akhirnya melakukan perjalan ke yang Transenden.

\section{Daftar Pustaka}

Bagus, Loren, 1991, Metafisika, Jakarta: PT. Gramedia Pustaka Utama.

Brandon, James R., 2003, Jejak-jejak Seni Pertunjukan di Asia Tenggara, diterjemahkan oleh R.M. Soedarsono,Bandung: P4ST UPI.

Cottingham, John, 1996, Western Philosophy, Cambridge: Balckwell.

Frondizi, Risieri 2001, Filsafat Nilai, diterjemahkan oleh Cuk Ananta Wijaya, Yogyakarta: Pustaka Pelajar.

Gallagher, Kenenth T., 2001, Epistemologi: Filsafat Pengetahuan, disadur oleh P. Hardono Hadi, Yogyakarta: PT. Kanisius.

Groslier, Bernard Philippe, 2007, Indocina Persilangan Kebudayaan, diterjemahkan oleh Ida Sudari Husen, Jakarta: KPG, Ecole Francaise d'Extreme-Orient, Forum Jakarta-Paris, Pusat Penelitian dan Pengembangan Arkeologi Nasional.

Hartoko, Dick, 2000, Manusia dan Seni, Yogyakarta: PT. Kanisius.

Holt, Claire, 2000, Melacak Jejak Perkembangan Seni di Indonesia, diterjemahkan oleh R.M. Soedarsono, Bandung: MSPI.

Kant,Immanuel, 1952, Critique of Jadgment, trans. J.C. Meredith, Oxford: Clerendon Press.

Kattsoff, Louis O, 1953, Elements of Philosophy, New York: Rolland Press.

Langer, Suzanne K., 1955,Philosophy in New Key, New York: A Mentor Book. 
Lombard, Denys, 2005, Nusa Jawa: Silang Budaya 1(Batas-batas Pembaratan), diterjemahkan oleh Winarsih Partaningrat Arifin (et. al.), Jakarta: Gramedia Pustaka Utama, Forum Jakarta-Paris, Ecole Francaise d'Extreme-Orient.

2005, Nusa Jawa: Silang Budaya 2 (Jaringan Asia), diterjemahkan oleh Winarsih Partaningrat Arifin (et. al.), Jakarta: Gramedia Pustaka Utama, Forum Jakarta-Paris, Ecole Francaise d'Extreme-Orient.

2005, Nusa Jawa: Silang Budaya 3 (Warisan Kerajaan-kerajaan Konsentris), diterjemahkan oleh Winarsih Partaningrat Arifin (et. al.), Jakarta: Gramedia Pustaka Utama, Forum Jakarta-Paris, Ecole Francaise d'ExtremeOrient.

Osborne, H., 1980, Foundations of the Philosophy of Value: An Explanation of Value and Value, London: Cambridge University Press,

Russell, Bertrand, 1950, History of Western Philosophy and its Connection with Political and Social Circumstences from the Earlies Times to the Present Day, London: George Allen and Unwin Ltd.

Sontag, Frederich, 1984, Elements of Philosophy, New York: Charles Schribner's Son. , 2001, Metafisika, diterjemahkan oleh Cuk Ananta Wijaya, Yogyakarta: Pustaka Pelajar.

Sunarto, 2015, Kebudayaan Posmodernisme: Percikan Pemikiran Jean Baudrillard,Yogyakarta: PT. Kanisius.

Pepper, Stephen, "A Brief of General Theory of Value", dalam Vergilius Ferm (ed.), 1950, A History of Philosophy System, New York: Philosophicsl Library.

The Liang Gie, 1979,Suatu Konsepsi ke Arah Penertiban Bidang Filsafat, Yogyakarta: Karya Kencana

Wahana, Paulus, 2005, Nilai Etka Aksiologi Max Scheler, Yogyakarta: PT. Kanisius. 